\title{
Absentee Ballot Day in the library
}

\section{Empowering students to vote}

O

n September 25, 2018, American University Library held its inaugural Absentee Ballot Day, helping 1,005 students request absentee ballots. The library partnered with student government, the alumni association, and the League of Women Voters of the District of Columbia to empower our students in exercising their fundamental right and responsibility as citizens in a democracy. This article describes the reasoning behind this initiative, the planning process, and the event itself. The hope is that many academic libraries will join in this effort for the 2020 general election. Resources for institutions wishing to hold their own Absentee Ballot Day are included.

\section{Why Absentee Ballot Day?}

Libraries and universities have an interest in discouraging students from joining the party of nonvoters for several reasons. They are values-based institutions committed to such fundamental aims as the pursuit of knowledge and promotion of human rights. Functionally, academia's educational mission is concerned with training new generations for positive participation in our societynot only in the economy, but also for active participation in democratic governance. Academia's research mission functions to create new knowledge-including knowledge that will never be profitable and therefore would not be created by business. Academic libraries have an additional responsibility for ensuring the preservation of knowledge for future generations. I dare to posit that if we, as academics, are producing graduates who are not engaged in our democracy, we have failed in our educational mission.

Apart from the idealist viewpoint, all institutions of higher education, including academic libraries, are financially dependent on government programs-including state school budgets, government-supported student financial aid, government-funded research grants, and nonprofit tax provisions. Furthermore, the fundamental values of academia and librarianship, such as an individual's right to privacy, can either be enhanced or harmed by government action.

We need an informed and engaged citizenry. Academic institutions mostly focus on helping students become informed critical thinkers. Absentee Ballot Day is about increasing student engagement in shared governance.

Many universities have robust voter registration drives, and we know that early voting experiences shape lifelong voter participation. ${ }^{1,2,3}$ However, college students face barriers to voting that registering students to vote at school may exacerbate.

Gwendolyn J. Reece is associate university librarian and director of research, teaching, and learning at the American University Library; email: greece@american. edu

(C) 2020 Gwendolyn J. Reece 
Voting in the city where an institution is located can be difficult for students. Students move frequently and must change their voter registration every time they relocate, which presents a barrier to participation. Moreover, students often are deeply tied to their home jurisdictions, making their voices valuable in local politics at home. Many plan to return to their home district upon graduation and will experience the long-term effects of any political decisions made while away at school. They should have a voice in those decisions. For the nearly 80,000 students a year who attend one of the nine colleges in Washington, D.C., including American University, there are additional barriers. Residents of the District of Columbia do not have full rights as citizens, including voting rights. ${ }^{4}$ This adds another confusing issue for our students to navigate. Students studying

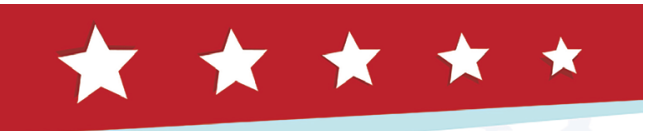

Tuesday, September 25 Absent,ee Ballot, Registirat,ion Dąy $8 \mathrm{am}-10 \mathrm{pm}$ Bender Library, First Floor

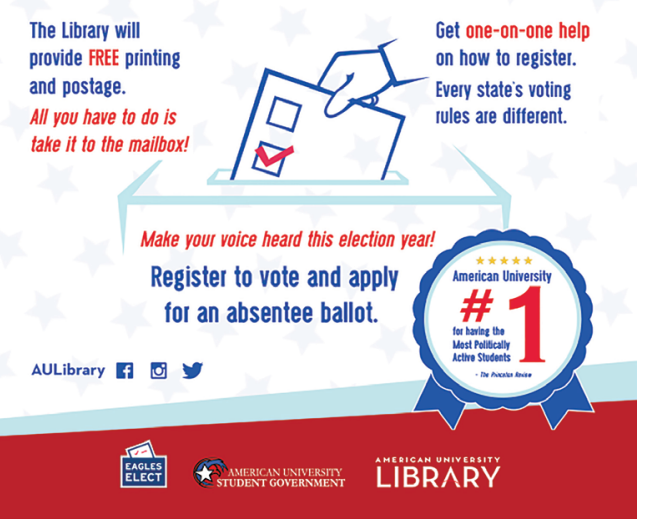

Absentee Ballot Day promotional poster, design by Erica Bethel. in the District of Columbia but voting in their home districts elect voting members of Congress, as opposed to the nonvoting representatives elected from the District of Columbia.

Although it is often preferable for students to vote in their home jurisdiction, many, even in-state students, cannot physically go to the polls. Having to travel and taking time away from school and/or work may be impossible. These obstacles are especially potent for low-income students. Voting absentee is an option for most students who are away at college to participate in elections. Requesting an absentee ballot presents its own challenges. Each state has a different process and requires different forms. Some jurisdictions have additional requirements that can be difficult to navigate, such as ID, signed witnesses, or hard-to-find information. Additionally, many of our students have no experience with "snail mail," nor with paper forms that do not incorporate automatic skip logic. We discovered that leaving fields blank caused significant anxiety.

Academic libraries have an information literacy mission to help students learn to use information for the purposes of being engaged citizens, not just for succeeding at university. This includes learning to navigate government information and identify reputable nonpartisan resources in order to make informed electoral decisions Given all these factors, American University Library decided to hold Absentee Ballot Day on National Voter Registration Day, which is the last day to register to vote and be guaranteed to meet the registration deadlines in all states.

\section{Partners and ethics}

The library reached out to student government about assisting with the event in August 2018. Student government wanted to do more voter empowerment, but the early fall deadlines are difficult since student government officers change annually and are often away during the summer. The planning for events like this must be largely complete before they return to campus, so they were grateful we provided some stability for the initiative and did the planning. 
We were grateful to them for doing marketing and outreach, which was more effective than the library could accomplish on its own. They also brought volunteers on the day of the event.

Our alumni association was already registering students to vote in the District of Columbia, which is troublesome given the lack of full voting rights described above. When I explained what we were doing, they joined and brought volunteers to the event. Finally, we worked with the League of Women Voters (LWV) of the District of Columbia. LWV is a strictly nonpartisan organization dedicated to citizen empowerment. They run VOTE411, which provides nonpartisan information on every race, including distributing the same survey to every candidate on even the most local elections and providing the answers so that voters can compare. They also provide nonpartisan analysis of what ballot measures mean. The LWVDC sent volunteers and provided us with cards about VOTE411.

It was crucial to us to be nonpartisan and strictly impartial about empowering people to vote. We chose our partners carefully and had volunteer instructions that articulated this commitment.

"This is ABSOLUTELY a non-partisan event. We cannot make any comment about any elected official, any candidate or any party during this event."

\section{Planning}

I proposed the project and, once approved by the university librarian, became the project coordinator. I created an overall plan and then invited relevant parties to a series of working meetings. I went through VOTE 411 for each state and identified all that needed IDs or had unusual requirements. I also tested and chose a portal site.

An important early step was determining the scope of what we would be providing. The cost was minimal. We offered:

- Stamps

- Envelopes

- Printing the forms
- Photocopies of IDs

- Assistance understanding forms

- We mailed the sealed, stamped envelopes

- Signed witnesses, where required

- Finding unusual information when necessary (original number associated with voter registration or codes for local precincts, etc.)

- VOTE411 cards

- "I registered Absentee!" stickers

We also decided to provide support to students once they received their absentee ballots. They could bring their ballot to the borrowing desk for a stamp. If they needed a signed witness, we would sign for them.

Working closely with library IT and building monitors, we planned our physical setup and did a full walk-through with them and with our partners who would be bringing volunteers. Some considerations were that the space needed to be tolerant of noise and able to handle lines. It took each student about ten minutes to fill out their paperwork. We had about a dozen computers. (We could have doubled that number.) We needed a printer/copier for printing the forms and copying IDs. This required a special power outlet and, therefore, partly determined our layout.

Student government was essential to our communication plan. They wrote several messages to the whole student body and posted them on their social media accounts. The library and our partners also promoted the event through social media. The library contacted the student newspaper to get an advanced story placed and hung posters around campus, on the library's front doors, and on our shuttles. The library's graphic designer created "I registered absentee" stickers on the model of the "I voted" stickers, and students wearing them generated word-of-mouth awareness. We also had volunteer "barkers" with signs wandering around campus the day of the event, telling students about it.

Prior to the event, we determined that we needed to make it easy for students to mail 
their applications, but we didn't want them to go through campus mail. We worked with our campus UPS store to buy stamps and to take the mail. We created a sealed box with a slot and always had a volunteer with it. At the end of the night, the box with the applications was locked in a private office until it was taken to the UPS store the next morning.

The planning team created a basic volunteer schedule. On the day of the event, there was always at least one member of the planning team present.

\section{What we did}

We staffed from 8 a.m. until 10 p.m., although we actually were available until 11 p.m., because we would not turn anyone away who was in line. We dedicated computers and a printer/copier. A white board listed states with voter ID requirements, and we added other unusual things as we found them. We made two copies of IDs, one for the application, another for the ballot.

Volunteers helped with way-finding, managed printing and copying, helped students navigate and understand the forms, distributed stamps and envelopes, told them about VOTE411, and instructed them to come back for a stamp or signature if they needed one when they got their ballot.

By the afternoon, the line wrapped all around the first floor of the library. We had students who patiently stood in line for an hour to participate. Students who had already registered brought their friends and stood in line with them again. For many members of the library staff, this was deeply moving.

\section{What they learned}

Students gained experience in navigating some government resources, and we were able to direct them to VOTE 411 as a model of a powerful nonpartisan tool for election information. They learned about paper mail and forms (many did not know how to address an envelope) along with experiencing a library as a place that empowers them to exercise their rights in a democracy. We hope they will carry this with them through- out their lives when they think about other libraries. Student comments demonstrated their realizations about our political system, like recognizing the differences in states' barriers, as they stood in line with students whose home states had removed or erected barriers.

\section{Going forward}

American University Library will offer this event again this year. We encourage other academic libraries to join us in the effort to increase student absentee voting for the 2020 general election, and are excited that several have committed to doing so. Our toolkit provides information for planning, including editable documents. Contact me by email or join our event listserv to learn more. Together, we can increase our students' engagement and participation in the upcoming general election.

\section{Notes}

1. Alan S. Gerber, Donald P. Green and Ron Shachar, "Voting May Be Habit-Forming: Evidence from a Randomized Field Experiment," American Journal of Political Science 47, no. 5 (2003): 540-50.

2. Eric Plutzer, "Becoming a Habitual Voter: Inertia, Resources, and Growth in Young Adulthood," American Political Science Review 96 no. 1: 41-56.

3. Markus Prior, "You've Either Got It or You Don't? The Stability of Political Interest over the Life Cycle," The Journal of Politics 72, no. 3 (2010): 747-66, doi:10.1017 /S0022381610000149.

4. The DC Human Rights City Alliance, The United Nations Association of the National Capital Area, and George Washington University Law School International Human Rights Clinic, "The Situation of Human Rights in the District of Columbia as Concerns the Lack of Statehood and Voting Rights as well as Entrenched Inequality and the Lack of Affordable Housing," United Nations Association of the United States of America, http:// unanca.org/images/DC_UPR_Report_2019. pdf (accessed December 12, 2019). z 